\title{
Assisteret befrugtning, en feministisk teoretisk udfordring?
}

\section{Af STine Willum Adrian}

\section{Abstract \\ Assisted reproduction; a theoretical challenge?}

Since Sulamith Firestones published: The Dialectic of Sex: The Case For Feminist Revolution (1970), an engaged debate between feminists has developed regarding the use of assisted reproduction. The technology has generated questions such as: Is assisted reproduction a technology of emancipation or suppression? Who should have access to assisted reproduction? And what happens to perceptions of concepts such as kinship and gender when assisted reproductive technologies are used?

In this review article I explore how assisted reproduction has played a crucial role in developing feminist theory, from radical feminism until today. I discuss and analyze how the different ethical-political agendas occurring due to the use of assisted reproductive technologies has provoked different perspectives of technology and reconceptualizations of gender and kinship.

\section{KEYWORDS}

Assisted reproduction, feminist theory, perspectives on technology, kinship, gender

Stine Willum Adrian er adjunkt i tekno-atropologi på Aalborg Universitet og tilknyttet det FKK-finansierede projekt (Trans)Formations of Kinship: Travelling in Search of Relatedness (KinTra). Adrian er i sin forskning optaget af feministiske teknovidenskabelige studier, og har udført flere etnografiske studier på danske og svenske fertilitetsklinikker og sædbanker 


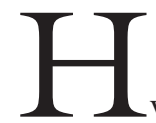

vem har gavn af anvendelsen af assisteret befrugtning? Den type spørgsmål har optaget feministiske teoretikere siden den første IVF-baby blev født. Teknologien har dog ikke blot fremprovokeret svar på bioetiske diskussioner, men har samtidig spillet en central rolle $\mathrm{i}$ udviklingen af feministisk teori.

Teknologierne, der går under samlebetegnelsen 'assisteret befrugtning', ' havde inden den første IVF baby Louise Brown blev født i 1978 skabt debat blandt feministiske teoretikere. Assisteret befrugtning har til formål at skabe børn, og består af grundteknologierne in vitro fertilisation (IVF) og insemination. IVF er en teknologi, hvor kvindens $x g$ udtages og befrugtes i en petriskål, hvorefter de befrugtede $x g$ opsættes i livmoderen efter nogle dage. Insemination kan i praksis være lavteknologisk og udføres ved at sprøjte sæd ind i skeden med en plastiksprøjte. Dog er der større chance for, at der opstår en graviditet, hvis der anvendes et tyndt kateter, og sxden placeres i kvindens livmoder, hvilket er almen praksis på fertilitetsklinikker i dag. Både insemination og IVF skaber mulighed for at anvende donorede kønsceller, og kan anvendes i sammenhæng med en surrogatmoder, dvs. en kvinde, der bærer graviditeten, men ikke skal være barnets moder.

Fordi assisteret befrugtning adskiller sex og reproduktion enten ved at kønsceller bliver befrugtet udenfor kroppen, eller ved at doneret sæd indføres i kvinden uden sex, udfordrer teknologierne eksisterende normer og forestillinger om køn, reproduktion, slægtskab og familiedannelse. Det har medført, at teknologien har haft væsentlige implikationer ift. udviklingen af feministisk teori, da det er temaer, der spiller en central rolle i den feministiske teori både før og efter at assisteret befrugtning blev udviklet eksperimentelt og anvendt som konventionel teknologi. Teknologien har med andre ord fremprovokeret utallige feministiske analyser, der blandt andet har rejst så forskellige spørgsmål som: Kan assisteret befrugtning skabe mulighed for, at kvinder kan frigøre sig, eller er det teknologier, der anvendes af patriarkatet til at få magt over kvinders reproduktion? Hvem skal have adgang til teknologierne og på hvilke præmisser? Og hvad sker der med kategorier som slægtskab og køn, når nye reproduktionsteknologier tages i anvendelse?

Formålet med denne review-artikel, er at undersøge spørgsmålet: Hvordan har anvendelsen af assisteret befrugtning veret med til at paivirke og udvikle feministers teknologisyn og teoretiske begrebsudvikling?

Mit fokus er således at undersøge, hvordan forskellige teknologisyn formes af og former kernebegreber heriblandt køn og slægtskab i de feministiske analyser, der har fundet sted med afsæt $\mathrm{i}$ assisteret befrugtning siden 70'erne. De tekstnedslag jeg foretager, er feministiske tekster med assisteret befrugtning som genstandsfelt, tekster, der aktivt har bidraget til feministiske teknologisyn og begrebsforståelser. Samtidig er det tekster der illustrerer, at denne diskussion har fundet sted globalt. På den måde har artiklen flere formål. Artiklen skal både illustrere, hvordan assisteret befrugtning påvirker begrebsdannelse og teknologisyn i feministisk teori, og skabe indsigt $\mathrm{i}$ den mangfoldighed af politiske og teoretiske muligheder feministiske analyser om assisteret befrugtning bidrager til.

Artiklen skal derfor ikke opfattes som en fortælling om hvordan feministisk teori forholder sig til andre videnskabelige discipliners teknologiforståelser. Det er heller ikke en modernistisk teleologisk fortælling af den feministiske teoris udvikling mod det bedre. Derimod er jeg inspireret af Lykkes anvendelse af begrebet kartografi, der åbner op for at skabe indsigt i begrebsmæssige genealogier (Lykke 2002) ${ }^{2}$. Men eftersom den teoretiske udvikling følger politiske processer og teknologiske forandrin- 
ger, er artiklen bygget op ved hjælp af en vis tidsmæssig kronologi.

Ligesom Braidotti ser jeg både i videnskabelig og politisk praksis nødvendigheden af udviklingen af pragmatisk teorianvendelse. Braidotti lancerede til det formål Deleuzes begreb "Nomadic Subjects" (1994). Det nomadiske subjekt skal forstås som en figuration, der efter behov udvikler teori i forhold til konkrete politiske/videnskabelige problemstillinger. Braidotti anvender selv figurationen i sit eget feministisk-teoretiske arbejde og liv, fordi hun har haft behov for at anvende forskellige strategier og begrebsliggørelser af køn, afhængigt af de problemstillinger, hun bliver konfronteret med. Da assisteret befrugtning er en overordnet beskrivelse af en række forskellige teknologier, der har forandret sig over tid, er figurationen 'det nomadiske subjekt' egnet til at tænke med.

I mine øjne har den feministiske teori og praksis brug for pragmatiske kartografier til at skabe refleksion over hvordan begreber udvikles i praksis, og hvordan de kan anvendes i forhold til forskellige konkrete politisk-etiske problemstillinger, som fx opstår når konglomeratet af forskellige teknologier anvendes til at skabe børn på utallige måder rundt om i verden. Derfor trækker artiklen på bidrag, der ikke kun kommer fra den anglo-saxiske verden. Det er yderligere en genealogi, der både tidligere og i dag spiller en central rolle i de teknologidiskussioner, der finder sted som en integreret del af $\mathrm{fx}$ science and technology studies (STS), og indenfor medicinsk sociologi og antropologi, hvilket også er illustreret i de teoretiske nedslag $\mathrm{i}$ artiklen. Ved at tydeliggøre den teoretiske mangfoldighed og bidrag som feministiske studier ift. assisteret befrugtning bidrager til, håber jeg også, at artiklen inspirerer til en videre teoretisk kreativitet og udvikling i feltet, knyttet op om reproduktive teknologier.

\section{ET OPGØR MED PATRIARKATET \\ - UTOPISKE RUGEMASKINER TIL DYSTOPISKE, MISOGYNE FREMTIDSSCENARIER}

Den radikalfeministiske forskning og teoriudvikling, der opstod i starten af 70'erne, var den første teoretiske retning, der for alvor blev udfordret af assisteret befrugtning. Udgangspunktet for radikalfeminismen var et politisk opgør med patriarkatet, og den teoretiske udvikling opstod som del af en politisk praksis.

Firestone kom til at spille en central rolle i den teoretiske debat, da hun som fortaler for udviklingen af de nye forplantningsteknologier skrev The Dialectic of Sex: The Case For Feminist Revolution (1970). Bogen er skrevet, inden IVF havde ført til det første barn, og kan derfor læses som en utopi. Det, der optog Firestone, var da heller ikke spørgsmålet om, hvordan man kan hjælpe infertile kvinder til at blive gravide. Det var et mere biologisk/strukturelt problem, der optog Firestone. Hun var interesseret i, hvordan man kan lave børn, uden at kvinder bærer graviditeten. Derfor fandt hun udviklingen af en kunstig livmoder lovende. Firestone mente nemlig ikke kun, at undertrykkelse i samfundet skyldes klasseforskellen mellem borgerskab og arbejdere. Den reproduktive kropsforskel mellem mænd og kvinder var i hendes optik et undertrykkende vilkår for alle kvinder. Hun ville derfor vende marxismen på hovedet ved at erstatte klasse med køn. Rugemaskinen var en teknologi med et radikalt samfundsændrende potentiale. Den kunne sikre kvindens ligestilling med manden, da graviditet og reproduktion herved blev adskilt fra kvindens krop.

Firestones fremtidsscenarium var dog langt fra ønskværdigt set fra andre radikalfeministers perspektiv (O'Brien 1981:7782,Arditti, Klein \& Minden 1984:1-7). Kritikken af assisteret befrugtning blev særligt formuleret efter det første IVF barn Louise Brown blev født i 1978. Kritikken kom bl.a. fra forskere og feministiske aktivi- 
ster som Arditti, Klein og Minden, der stod bag antologien "Test-Tube Women: What Future for Motherhood” (1984), og Corea, Klein, Hanmer, Holmes, Hoskins, Kishwar, Raymond, Rowland og Steinbacher, der redigerede "Man-Made Woman: How New Reproductive Technologies Affect Women" (1985). Koch og Petersson tog i en dansk sammenhæng samme position (Koch 1989, 1992; Peterson 1995). Det var på mange måder en meget entydig kritik, der blev formuleret på en række feministiske konferencer, hvor netværket FINRRAGE (Feminist International Network of Resistance Against Reproductive and Genetic Engineering) blev dannet.

Kritikken mod udviklingen og anvendelsen af IVF og andre forplantningsteknologier var baseret på en opfattelse af, at teknologierne var et middel, mænd kunne bruge til at opnå endelig kontrol med kvindens reproduktion. I modsætning til Firestone mente kritikerne, at brugen af assisteret befrugtning ville fastholde og videreudvikle den eksisterende patriarkalske samfundsstruktur. De argumenterede bl.a. med, at teknologierne ville give mænd (dvs. læger og andre videnskabsmænd) muligheden for at styre skabelsen af liv; en magt, der tidligere havde været kvindens. Fra at mændene i en radikalfeministisk optik havde haft kontrol med kvindens seksualitet, fik de også magt over kvinden som reproduktivt objekt. Det var ikke mindst et scenarium som Corea uddybede i en række artikler (Corea 1984, 1989a, 1989b). Kritikken byggede også på en opfattelse af, at kvinder bliver udsat for en objektivisering, der opstår ved, at kroppen betragtes som den nødvendige livmoder/container, hvor fostret bliver til. Dette er en proces, der legitimerer eksperimenter med kvindekroppe, samtidig med at den skaber fostret som patient, og giver kvinden følelsen af skyld og utilstrækkelighed, hvis barnet ikke er perfekt ved fødslen (Rothman 1986:114). Det er en objektivisering, der ifølge radikalfeministerne samtidig er med til at kommerciali- sere reproduktion, kvindekroppe og kropsdele. I bogen The Mother Machine (1985) udvikler Corea yderligere begrebet "breeding brothels", hvor surrogatmoderskab implicit sidestilles med prostitution. Begrebet anvender hun til at problematisere kommercialiseringen af xgdonation og surrogatmoderskab, der efter Coreas mening lægger op til køb og salg af kvinders kroppe, kønsceller og organer (Corea 1985a: 272-282). På trods af forskellene mellem Firestone, der gennem en teknofil position ser teknologi som en frigørende mulighed for kvinder ift. det undertrykkende patriarkat, og de andre radikalfeminister, der positionerer sig som teknofobe ved at indskrive en deterministisk, patriarkalsk magt i reproduktionsteknologierne, så er hovedformålet at udfordre den kønsorden som etableres gennem patriarkatet. I både den teknofile og teknofobe radikalfeministiske position tilskrives kroppen og teknologien en vis form for determinisme. Blandt FINRRAGE-fortalerne var der dog også feminister, der støttede anvendelsen af mindre teknologier som selvinsemination. I modsætning til IVF blev selvinsemination og udviklingen af frivillige donorkorps set som en måde at styre reproduktionen og skabe mulighed for andre familieformer, hvilket også skabte mulighed for at bryde med kernefamilien. Feministiske grupper begyndte fx systematisk at udbrede kendskab til selvinseminationer med doneret sæd. Her blev foreslået forskellige lettilgængelige teknologier som fx et køkkenredskab, der i USA og England anvendes til at fylde kalkuner med $^{3}$ og engangssprøjter uden nål, se Hornstein (1984:373-381).4

Hovedparten af den tidligere radikalfeministiske forskning var ikke etnografisk, men baserede sig på analyser af juridiske sager eller analyser af de problematiske potentialer, radikalfeministerne antog at teknologierne $\mathrm{i}$ forbindelse med assisteret befrugtning havde. Derfor var der få analyser af, hvad der konkret foregik på fertilitetsklinikken, og af hvordan personalet oplevede 
deres arbejde. Det indgik ikke i deres begrebsdannelse. Det kan skyldes, at radikalfeministernes analytiske udgangspunkt var teknofobisk, og at de så kvindeundertrykkelsen som en præmis for teknologien. De infertile kvinder bliver med andre ord til ofre for et samfundsskabt begær efter at få et barn (Klein 1989, Koch 1989). Herved lader de kvinders kroppe blive objekt for det patriarkalske, medicinske blik. Det er en position, der ikke skaber rum til at forstå, hvorfor kvinder, med og uden partnere, vælger at gennemgå fertilitetsbehandling, eller hvorfor bioanalytikere, sygeplejersker og læger (hvoraf der er kvinder iblandt) deltager i skabelsen af børn ved hjælp af teknologi.

Radikalfeministernes syn på relationen mellem kultur og natur har været baseret på en dikotomisk forståelse, der samtidig definerer mænd og kvinder som radikalt forskellige pga. køn. I deres kritik af de nye forplantningsteknologier findes implicit en forståelse af, at køn ikke er noget, man gør, det er noget man er. I denne forståelse bliver det som kvinde frigørende at se og dyrke styrken i den kvindelige reproduktive krop uden teknologi. Med undtagelse af Firestones position er teknologi og videnskabelig udvikling mest gavnligt for mænd og ikke kvinder.

Selvom Firestone og de andre radikalfeminister indtager forskellige syn på teknologiens muligheder og konsekvenser, har de dog meget tilfælles ift. teknologisyn. Begge positioner baserer sig på en opfattelse af, at kroppe såvel som samfundsændringer kan styres og determineres ved hjælp af teknologien. Herved har teknologien enten et undertrykkende eller et frigørende potentiale for kvinder 5 . Fælles er samtidig det overordnede formål, at nedbryde den patriarkalske magtordning.

\section{INFERTILE FEMINISTERS OPGØR}

MED TABU OG TEKNOFOBI

Radikalfeministernes entydige kritik blev relativt hurtigt udfordret af teknologien, der blev forbedret, så der var færre bivirkninger ved hormonstimulering og xgudtagningerne, samtidig med at chancen for at fă barn ved hjælp af teknologierne steg, da fertilitetspersonalet på klinikkerne blev rutineret $i$ at udføre behandlingerne ${ }^{6}$. Samtidig var der infertile feminister, der oplevede et skisma mellem deres drøm om at få børn ved hjælp af assisteret befrugtning og de radikalfeministiske synspunkter, der kunne opleves som stigmatiserende for ufrivilligt barnløse, der så en mulighed for at få barn via de nye teknologier.

Herved opstod der et andet udgangspunkt for teknologiforståelse og vidensproduktion. Infertile feminister begyndte derfor at kritisere radikalfeministernes teknofobe teknologisyn, og det infertilitetstabu de implicit mente fulgte med. Denne problematisering udtrykte Pfeffer og Wollett allerede i 1983 i bogen The Experience of Infertility; om kvinders oplevelse af infertilitet. Både Pfeffer og Wollett var infertile og undrede sig over, hvorfor infertilitet ikke blev diskuteret mere blandt feminister, som et problem mange kvinder oplevede i deres liv. Pfeffer gik videre i sin kritik i 1985 , hvor hun udgav en artikel i det radikalfeministiske tidsskrift, Trouble and Strife. I artiklen problematiserede hun ikke mindst den offerrolle, som radikalfeministerne placerede infertile kvinder $i$, og hun satte spørgsmålstegn ved radikalfeministernes teknofobe teknologisyn, (Van Dyck 1995: 99-102).

Derudover opstod i løbet af 80'erne forskellige skift i den feministiske forskning. En af disse forandringer var, at en række kvinder, der var uddannet og forskede inden for det naturvidenskabelige felt, deltog i de feministiske debatter og den teoretiske udvikling. Pga. deres egen naturvidenskabelige baggrund havde de en anden indgang til kritik af videnskab og teknologiudvikling end den radikalfeministiske. I stedet for at afvise teknologien knyttede de den feministiske kritik til deres naturvidenska- 
belige forskning. Det gjorde, at de i stedet undersøgte de undertrykkende mekanismer, der til tider er en del af de videnskabelige praksisser, teknologiudvikling og teknologianvendelse, uden at afvise teknologien (Birke 1986, Haraway 1991, Oudshoorn 1994). Sxrligt Haraway har lige siden spillet en væsentlig rolle i forhold til udviklingen af tanketeknologier og begreber til at forstå samspillet mellem teknologi, mennesker og vidensproduktion (Haraway 1997:173-212). For eksempel publicerede Haraway allerede i 1984 en tidlig version af The Cyborg Manifesto (Haraway 1991:149), og hendes tilgang til vidensskabsteori, Situated Knowledges blev formuleret i 1987 (Haraway 1991:183). Det er et oplæg til at studere teknologi situeret, hvilket også byggede på den type kritik som de infertile feminister lancerede ift. radikalfeminismens strukturelle kritik, der ikke inkludererede de konkrete problemstillinger og erfarede liv som infertile stod overfor.

Behovet for analyser, der understreger kvinders forskellighed, og et mere eksplorativt teknologisyn er ligeledes udgangspunktet for Stanworth og rækken af bidragsydere til antologien: Reproductive Technologies: Gender, Motherhood and Medicine (1987). De positionerer sig anderledes end radikalfeministerne ved at fokusere på de komplekse problemstillinger, der rejser sig for brugere af de mange nye forplantningsteknologier (Stanworth 1987:8-9). Artiklerne i antologien diskuterer alt fra ultralydsteknologien til IVF. Det gennemgående for artiklerne er, at de forsøger at skabe en kritisk analytisk indgang til teknologierne, uden at fastholde den samme form for teknofobi som radikalfeministerne. Samtidig lægger Stanworth et al. vægt på at inkludere forskellighed blandt både kvinder og mænd, og herunder ikke blot forskelle, der er kønspecifikke.

Udgangspunktet er at fastholde en kritisk tilgang til konsekvenserne af anvendelsen af teknologierne, uden på forhånd at afvise teknologierne. Analyserne inkluderede med andre ord ikke et deterministisk teknologisyn som radikalfeministernes, hvor teknologien i udgangspunktet havde en iboende frigørende eller undertrykkende kraft. I stedet undersøges hvilke problemstillinger og muligheder, der opstår, når forskellige kvinder formet af bl.a. alder, klasse, race og seksualitet anvender eller ekskluderes fra anvendelsen af teknologien, som i øvrigt kan være meget forskellig afhængig af om IVF anvendes og om anvendelsen inkluderer kønscelledonation og surrogati. Analysen skaber et syn på teknologien som et redskab, der kan anvendes til at overkomme infertilitet, men som samtidig kan være med til at skabe ulighed. Herved giver teknologien mulighed for et analytisk blik på ulighed, magtrelationer og stigmatiseringer. Køn bliver her en kategori, der er kompleks og skal forstås intersektionelt i samspil med andre sociale kategorier. Stanworth et al. anvender her hvad Lykke omtaler som en implicit intersektionel strategi (Lykke 2008:105).

\section{TEKNOLOGI SOM VINDUE TIL NORMER OM KØN, SLÆGTSKAB OG FAMILIEFORESTILLINGER}

Teknologisk udfordrer assisteret befrugtning begreber om slægtskab og familiedannelse, for med assisteret befrugtning adskilles celler og kroppe. Et barn kan have to biologiske mødre, når xgdonation anvendes. Både kvinden, der bærer barnet under graviditeten, og kvinden, der med sine $x g$ giver ophav til halvdelen af barnets genetiske materiale, er biologisk tilknyttet ved enten blodsbånd eller genetisk arvemasse. I USA og England anvender visse lesbiske par denne mulighed til, at begge kvinder bliver biologiske forældre til deres barn, selvom kun én af dem kan bidrage med genetisk materiale. Teknologien skaber også mulighed for, at ældre kvinder og mænd kan blive forældre - med donoræg er der ingen aldersgrænse for, hvor længe en kvinde kan bære en graviditet, og adskillelsen af 
sex og reproduktion tydeliggør muligheden for, at kvinder uden partner og lesbiske kvinder kan få børn uden at involvere mænd i reproduktionen. Teknologien er herved med til at synliggøre, muliggøre og problematisere kulturelle konventioner knyttet til slægtskab og familiedannelse. En ting er dog muligheder for anvendelse af teknologien, men muligheder medfører ikke nødvendigvis brud på konventioner, der ligeså vel kan reproduceres.

Med det stigende globale brug af assisteret befrugtning er der opstået en feministisk/etnografisk interesse $i$ at undersøge, hvordan teknologierne i praksis anvendes globalt. Hvad betyder brugen af teknologierne i praksis ift. slægtskab og køn? (Strathern 1992; Franklin 1997; Tjørnhøj-Thomsen 1999; Becker 2000; Kahn 2000; Inhorn 2003; Throsby 2004 ; Thompson 2005; Adrian 2006; Almeling 2007; Spilker 2008; Roberts 2012). Særligt slægtskabsopfattelser og den måde de i en Vestlig kontekst knytter sig til forestillinger om biologi og det naturlige, har været centrale for analyser, der er kommet til at bidrage til udviklingen af den feministiske socialkonstruktionisme såvel som queerteori.

Strathern og Franklin har været to af de første antropologiske kønsforskere, der har videreudviklet slægtskabsbegrebet $\mathrm{i}$ analyser, der fokuserer på assisteret befrugtning. Strathern tog bl.a. problemstillingen op i "Reproducing the Future: Anthropology, Kinship, and the New Reproductive Technologies” (1992) ved at sammenligne slægtskabsopfattelser i Malaysia med de, der kom til udtryk i England efter indførelsen af assisteret befrugtning. Slægtskab var også det centrale tema i Franklins "Embodied Progress: A Cultural Account of Assisted Conception” (1997), hvor hun undersøger, hvordan slægtskaber udvikler sig i et sundhedssystem præget af Thatcherism.

Franklin, der bevæger sig i krydsfeltet mellem antropologi, science and technology studies og kønsforskning, beskriver i artiklen "Bioligization Revisited: Kinship The- ory in the Context of the New Biologies" (2001), hvordan de teoretiske diskussioner om køn, slægtskab og natur/kultur, der har fundet sted ift. bl.a. assisteret befrugtning, skal ses i lyset af “jomfrufødselsdebatten".7 I Franklins øjne har jomfrufødselsdebatten og den måde køn og slægtskab er diskuteret $\mathrm{i}$ antropologi og feministiske teori i forbindelse med anvendelsen af assisteret befrugtning været med til at udvikle den socialkonstruktionistiske begrebsliggørelse. Jomfrufødselsdebatten er en debat, der udviklede sig blandt vestlige antropologer, der undrede sig over, hvorfor der findes befolkningsgrupper, som ikke mener, at manden deltager i tilblivelsen af børn. I Franklins analyse af jomfrufødselsdebatten beskriver hun, hvordan slægtskabs- og kønsopfattelser er blevet anvendt til at rekonstituere hinanden ved at blive tilskrevet et biologistisk indhold. Det er bl.a. sket, fordi det fysiske faderskab blev opfattet som et centralt, socialtorganiserende princip i antropologien (Franklin 1997: 17-72, 2001: 305-307). Derfor kunne det for en vestlig antropolog, der bar sine egne forestillinger om slægtskab med på feltarbejde, være svært at forstå, at det samfund, der var under antropologens blik, ikke knyttede manden til tilblivelsen af børn. Med anvendelsen og udbredelsen af assisteret befrugtning - en teknologi der i sig selv udfordrer det biologiske slægtskab og køn pga. adskillesen af sex og forplantning, opstod der et nyt konkret feministisk antropologisk genstandsfelt, der var med til at skabe en ny indgang og opmærksomhed på at analysere samspillet mellem reproduktion, slægtskaber og køn. Den denaturalisering af slægtskabet, som blev tydelig i disse analyser, blev herved anvendt til at denaturalisere køn og vice versa. Det skete for eksempel i Butlers omskrivning af kønsbegrebet. Franklin forklarer:

In Gender Trouble (1990), Judith Butler took direct inspiration from feminist anthropology to recast the relation of sex to gender, or bi- 
ology to embodiment, in what remains one of the most influential "denaturalizations" of biological facts to emerge from within feminist scholarship in the 1990s (...) Butler proposes a model that radically repositions allegedly natural facts as an effect of gender categories, rather than the reverse (Franklin 2001: 309-310).

Butlers analyse har efterfølgende været helt grundlæggende for den socialkonstruktionistiske kønsforskning og har været med til at denaturalisere biologiske forklaringsmodeller både af køn og slægtskab. De socialkonstruktionsitiske analyser har bl.a. ved hjælp af Butlers og hendes udvikling af diskursive materialisering gennem en citerende performativ praksis skabt mulighed for at undersøge, hvordan materialiseringer af køn, krop og slægtskaber opstår (Butler 1993:1$23)$. Der har i analyserne været specifikt fokus på, hvordan subjekter, materialiteter i form af kroppe eller familier opstår i praksis. Disse analyser har i den grad haft en særlig politisk kraft. Ikke mindst ved i gentagende analyser at illustrere, hvordan assisteret befrugtning reguleres og praktiseres gennem en reproduktion af den heteroseksuelle kernefamilie via stigmatiseringer og eksklusioner af bl.a. lesbiske og enlige kvinder. I en dansk kontekst har denaturaliseringen af forældreskab haft en særlig betydning for de kønsteoretiske analyser, der blev udformet i forbindelse med perioden 1997-2007, hvor fertilitetsbehandling var ulovlig at udføre for læger (Bryld 2001; Stormhøj 2002; Adrian 2006, 2010, Petersen 2009).

Assisteret befrugtning og queerteori har dog ikke entydigt medført et opgør med naturaliseringer blandt lesbiske. Mamo viser gennem sine analyser, hvordan amerikanske lesbiske kvinder $\mathrm{i}$ deres anvendelse af assisteret befrugtning har været med til at bryde med heteronormativitet, samtidig med at de også rekonstituerer naturaliserede forestillinger om, hvad en familie og ikke mindst en kvinde opfattes som (Mamo 2007:232-234).
De mange etnografiske studier af anvendelsen af assisteret befrugtning, hvor køn, slægtskab og forestillinger om natur/kultur bliver forhandlet forskelligt, illustrerer, at teknologien har spillet en vigtigt rolle $\mathrm{i}$ form af et vindue til hvilke normative landskaber og praksisser, der udfolder sig globalt, når assisteret befrugtning tages i brug. Analyserne får herved synliggjort og problematiseret hvilke familieformer og forældreskaber, der opfattes som legitime og illegitime. I de socialkonstruktionistiske analyser bliver begrebsdannelsen af køn og slægtskab udviklet med det politiske formål at denaturalisere køn og slægtskab. Dvs. de gør op med den tidligere essentialistiske slægtskabsforståelse, såvel som de essentialistiske forståelser af køn, radikalfeministerne baserede sig på. Denne begrebsliggørelse har åbnet op for at familie, køn og slægtskab kan gøres og tænkes på andre måder end $\mathrm{i}$ en heteronormativ ramme, og køn bliver en kategori, der i den grad er formbar. Teknologien skaber derfor i et socialkonstruktionistisk udgangspunkt både en mulighed for nytænkning ift. køn og slægtskab, og mulighed for fastholdelse af en heteronormativ familieforståelse. Det er således ikke teknologien, men de mennesker, der anvender den, som det analytiske blik fokuserer på i forandringsprocesser. Man kan med andre ord sige, at samtidig med, at analyserne gør op med en opdeling mellem natur/kultur, så er de i den måde de etablerer deres genstandsfelt på med til at skabe en distinktion mellem det materielle og diskursive, da der analytisk er fokus på, hvordan materialiseringer finder sted via sociale konstruktioner, ikke omvendt.

\section{NÅR KROP OG CELLER \\ TILSKRIVES AGENS}

Samtidig med at assisteret befrugtning har været med til at udvikle forståelser af slægtskab og køn i en socialkonstruktionistisk forståelsesramme, bliver de socialkonstruktionistiske analyser, og analyser, der hoved- 
sageligt fokuserer på sociale processer, udfordret af teknologien i praksis. Det skyldes både en kritik af den disciplinære opdeling mellem naturvidenskab og humaniora/ samfundsvidenskab, der kan føre til, at materialiteter ikke medtænkes i analyser (Haraway 1991, Barad 2007, Adrian 2006). Samtidig er det er også en kritik, der er formet af de hændelser, der finder sted på fertilitetsklinikken. På en fertilitetsklinik skaber man børn, der ikke ellers ville være blevet til - men der er også mange kvinder og par, der forlader klinikkerne uden børn. At skabe børn på en fertilitetsklinik, er med andre ord en materialiseringsproces, hvor det materielle kan have afgørende betydning - og teknologier, kroppe og celler kan overraske. Materialiteterne kan have agens - eller med andre ord de kan have forandringspotentiale. Det er den slags materielle overraskelser, der ligger i Haraways videnskabsteoretiske udgangspunkt, og som forklarer hvad materiel agens er, og hvordan den udfordrer sociale normer. Denne position omtales også i dag som nymaterialisme, selvom den ikke er ny og har rødder tilbage til de tidlige $80^{\prime} \mathrm{ere}^{8}$. Det er en forståelse af teknologi og materialiteter, der implicit er at finde i Donna Haraways cyborgfiguration, der er udviklet til at problematisere den teknofobi, der var at finde i radikal- og økofeministiske teknologianalyser (Haraway 2001: 149-182).9

Cyborgen er da også en meget anvendt figuration $i$ analyser af assisteret befrugtning. ${ }^{10}$ Ved at arbejde teoretisk med figurationen, er udgangspunktet hverken teknofilt eller teknofobisk. I stedet åbner den op for at undersøge de magtrelationer, der findes i praksisser, og som bliver del af materialiseringsprocesserne. Derudover muliggør figurationen analyser, hvor materialitet har agens. Davis-Floyd og Dumits anvendte tilmed cyborg-figurationen som ramme for antologien "Cyborg Babies: From Techno-Sex to Techno-Tots” (1998: 1-18). De udvikler figurationen, så den indeholder fire forskellige teknologisyn, som illustreres i antologi- ens forskellige bidrag. Cussins/Thompson er en af de etnografiske forskere, der har taget udgangspunkt i Haraways forståelse af cyborgbegrebet og arbejder videre med, hvordan materiel agens făr betydning, når forældre bliver til på fertilitetsklinikker (Cussins 1996; Thompson 2005). Thompson har bl.a. haft dette fokus, fordi de kvindelige patienter, hun observerede under sit studie, ikke, som den tidligere radikalfeministiske kritik beskrev, ensidigt lod sig objektgøre af det patriarkalsk-medicinske blik. Den objektgørelse kvinder deltager i, foregår ifølge Cussin ofte $\mathrm{i}$ et større samspil mellem kvinder, arbejdsorganiseringen på fertilitetsklinikken og personalet. En objektivisering af kroppen kan for eksempel udspille sig med aktiv deltagelse af kvinden, for at den gynækologiske undersøgelse ikke skal opleves som ubehagelig. Under den gynækologiske undersøgelse kan objektgørelsen af kvindens æg og et aktivt fokus væk fra hele kroppen til dele af kroppe på ultralydsscanneren være med til at afseksualisere situationen. I denne proces finder der konstant ontologiske skift sted, hvilket Cussins/Thompson beskriver vha. begrebet “ontologisk koreografi” (Cussins: 1996).

Ontologisk koreografi anvender Cussins/Thompson samtidig til at fange de ontologiske skift som materialiteter gennemgår på en klink. Skift der sker i mødet mellem kroppe, normer, jura, celler og teknologi. For eksempel når embryonet skifter fra at være et muligt barn opbevaret i frysetanken, til at være affald pga. juridiske rammer for hvor længe, embryonet må opbevares i fryseren.

Cussins/Thompsons interesse for, hvad der sker med patienterne i mødet med teknologien, gør, at hendes analytiske forhandling af natur/kultur-distinktionen adskiller sig fra en del af de andre studier. Det skyldes, at hun som Haraway opfordrer til at inkludere materialitetens agens. Dette ændrede fokus har samtidig betydning for, hvordan hun begrebsliggør køn. Samtidig med at hun bygger på Butlers problemati- 
sering af den heteroseksuelle normativitet, tilskriver hun køn en materialitet, der ikke kun er formet af diskurser, men i højre grad også af materialitetens agens.

Med inspiration fra Cussins/Thompson, Haraway og Barads teori om agential realism, har Adrian sidenhen undersøgt hvordan skabelser (materialiseringer) finder sted på fertilitetsklinikker og sædbanker i Danmark og Sverige (2006). Agential realism er en teori, der bygger videre på Haraways videnskabsteoretiske forståelse af situeret viden. Den udfolder denne position i samspil med Niels Bohrs epistemologi for at skabe en teori over hvordan verden og viden materialiserer sig både via sociale, kulturelle og materielle processer. Adrian forsøger at fange hvordan $x g$, sæd og embryoner $\mathrm{mm}$. skabes både via nye skabelsesberetninger, der cirkulerer som bl.a. (visuelle)historier $\mathrm{i}$ medier og reklamer, og via praksisser, når kroppe, celler og teknologier mødes på sædbanker og fertilitetsklinikker. Hun er med andre ord interesseret $\mathrm{i}$ forandringsprocesser. Igennem sin analyse følger hun xgget, sædcellen og embryonet. Det gør hun for at få indsigt i forandringer og materialiseringer, der finder sted ift. bl.a. slægtskab og køn, når patienter, personale og politikeres holdninger til slægtskab og kønsceller mødes (Adrian 2006)11. Kønsdimorfisme er her udgangspunktet for at undersøge, hvordan krop og celler tager del i at skabe forandring. Ved at tage udgangspunkt i ægcellen, sædcellen og embryonet skabes mulighed for netop at undersøge forskellige kropslige betingelser for agens og forandring, samtidig med at hun undersøger hvordan materialiseringer opstår diskursivt.

Ved at tilføje materialitetens agens - og herved ikke blot nedbryde skellet mellem natur/kultur, men også mellem materialitet/diskurs såvel som objekt og subjekt bliver det muligt at få syn for andre former for forandrings- og materialiseringsprocesser. Teknologien, celler og kroppe kommer i disse analyser til at være en medaktør, der er er med til at forme forandringer i samspil med normer, kroppe mm. Teknologien er således ikke determinerende, frigørende eller undertrykkende, men den er heller ikke ensidigt formet af menneskelige diskurser, der skaber kroppe, som den typisk gøres i socialkonstruktionistiske analyser. Den indgår i skabelsen af uligheder og muligheder, herunder også i skabelsen af slægtskab og køn. Nymaterielle analyser er således fokuserede på at undersøge materialiserings- og forandringsprocesser, der både skaber normative og materielle forandringer på tværs af materialiteter og diskurser samtidig med at de fastholder væsentligheden ved inspireret af Leigh Star, at stille spørgsmål til teknologien: Qui bono? Hvem făr noget ud af teknologien? Et spørgsmål, som også kan argumenteres har været grundlæggende for den tidlige kritik af radikalfeministerne såvel som i de socialkonstruktionstiske analyser (Leigh Star 1991:43) .

\section{NÅr CELLER OG KROPPE SÆLGES OVER GRÆNSER}

Fra assisteret befrugtning blev udviklet, har ønsket om at få et barn fået mænd og kvinder til at rejse over grænser for at få adgang til teknologien. Baggrunden for fertilitetsrejser er, at behandling ikke er tilgængelig, er af for ringe kvalitet lokalt, at den kan opnås billigere i et andet land, eller fordi lovgivningen ikke tillader den ønskede behandling (Inhorn 2011). Med udbredelsen af internettet har fertilitetsbehandling og salg af $æ g$, sæd, embryoner og surrogatmødre i stigende grad udviklet sig til et transnationalt marked, og har sat fokus på mobilitet og kommercialisering af reproduktiv kropsdele. I dag kan man rejse til Barbados for at få fertilitetsbehandling i et afstressende miljø, man kan rejse til Danmark for sæddonation, til Grækenland efter xgdonation eller til Indien efter en surrogatmoder. Den øgede mobilitet har på ny udfordret den feministiske teori, så transnationale slægtskaber og økonomi analytisk er 
kommet i fokus. Det har blandt en række feministiske teoretikere og forskere medført, at en mere strukturalistisk kritik af kommercialisering af kropsdele har udviklet sig med mange parallelle pointer tilfælles med de tidligere radikalfeministiske analyser (Waldby \& Mitchell 2006; Dickenson 2008). Også analyser af kropsforskelle og økonomi er blevet udfoldet som industrien i forbindelse med xgdonation og sæddonation er vokset. Almeling har bl.a. sammenlignet hvordan $x g$ og sæd kommercialiseres og sælges i USA. Hun illustrerer, at både kropsforskelle på mænd og kvinder og kønnede kulturelle forestillinger er væsentlige at inkludere og undersøge i en analyse, fordi de făr betydning for diskurser og prissætning af $x g$ og sæd i et kommercielt sundhedsvæsen som det amerikanske (Almeling 2007).

Vestlige kvinder og par der nu rejser til Indien for at anvende en billig surrogatmoder kalder på post-koloniale analyser. Der er lige nu adskillige feministiske forskningsprojekter i gang som følge af, at Indien de sidste år er blevet et fertilitetsmekka (Kroløkke \& Pant 2012; Pande 2010; Rudrappa 2012). Kommercialiseringen af kropsdele skaber dog også bevægelser til vestlige lande som fx Danmark hvor sædbanksindustrien er i vækst. Det kalder på andre intersektionelle analyser, der inkludere forståelser af subversive strategier for at få børn (Adrian 2010).

Analyserne af fertilitetsrejser og transnationalt salg af kropsdele rettet mod forplantning fordrer derfor anvendelsen og videreudviklingen af analyser, der udvikler intersektionelle og postkoloniale analyser i et bioøkonomisk perspektiv. Teknologien bliver ikke som i de tidligere radikalfeministiske analyser betragtet som deterministisk ift. et entydigt frigørende eller undertrykkende potentiale knyttet op om patriarkatet. I stedet forstås den typisk i disse analyser ud fra økonomiske rationaler, der er i spil i fertilitetsindustrien. Køn kan i disse analyser forstås essentialistisk, men bliver ikke nødvendigvis bundet $\mathrm{i}$ universaliserede faste kategorier. Det analytiske fokus kan blive anvendt til både at undersøge reproduktion af ulighed og subversive strategier til at overkomme dem.

\section{KONKLUSION}

Assisteret befrugtning er et teknologisk genstandsfelt, der til stadighed vakker feministisk interesse og debat. Interessen for feltet har været konstant siden Firestone lancerede sin teknofile position i 70'erne. Dengang var Firestones formål at omvælte patriarkatet og ligestille kønnene. I dag er fokusset ændret til at undersøge hvordan de transnationale økonomiske bevægelser af kroppe og kønsceller finder sted med hensigten at skabe børn, eller at undersøge de mangfoldige skabelser, der finder sted på en fertilitetsklinik.

I denne review-artikel har jeg inspireret af Braidottis figuration det nomadiske subjekt undersøgt, hvordan anvendelsen af assisteret befrugtning har været med til at påvirke og udvikle feministers teknologisyn og teoretiske begrebsudvikling.

Når man læser sig gennem den feministiske litteratur om assisteret befrugtning, er et af de fascinerende træk, hvor mange forskellige teknologisyn, der har formet sig gennem tiden, med forskellige politiske potentialer, og forskellige begrebsliggørelser af køn og slægtskab i spil. Taget i betragtning af, at feministisk teori deler forestillingen om, at etablere et kritisk blik på køn evt. i samspil med andre kategorier, er det interessant, at teknologi, magt og agens bliver konceptualiseret så forskelligt. En del af forklaringen skal findes $\mathrm{i}$ de positioneringer som analyserne foretages fra. For radikalfeminismen (både den teknofile og teknofobe), handler analyserne af teknologien om et opgør med patriarkatet, den maskuline dominans og det ulige samfund - her udfoldes teknologiforståelsen langt fra brugerne af assisteret befrugtning. 
Det er netop distancen til teknologien og dens brugere, der havde den uintenderede effekt, at reproducere det infertilitetstabu som også ufriviligt barnløse feminister oplevede. De følte sig derfor ramt af den radikalfeministiske analyse, stigmatiseret og offerligjort. De første feministiske modsvar til radikalfeminismen var derfor i høj grad et opgør med distancen til teknologien, brugerne og de kvinder, der drømte om at fă børn via teknologi.

Med udgangspunkt i Haraways begreb situeret viden, medfører den distancerede analyse, at man som forsker mister ansvarlighed for de konsekvenser ens analyse må have for involverede aktører i form af bl.a.mennesker, dyr og planter (Haraway 1991). Der sker også noget med kompleksiteten ift. magt og ulighed, når man kommer tæt på den teknologiske anvendelse. Tæt på bliver den teknologiske kompleksitet tydelig. I den første feministiske kritik af radikalfeministerne opløses det essentialiserede køn, der knytter kvinder til det naturlige og mænd til det kulturelle. Det sker fordi politiske og subversive potentiale i denne forste kritik af radikalfeministerne handlede om at skabe en forståelse af ufrivillig barnløshed. Det betyder ikke, at analyserne ender i en teknofil position. I stedet tydeliggør de behovet af intersektionelle analyser, der bør tages i brug for at forstå det nexus af problemstillinger, der kan opstå ift. teknologierne ved deres konkrete brug. Det politiske potentiale ligger med andre ord i at undersøge mange forskellige ufrivilligt barnløses erfaringer.

Skiftet mod etnografiske analyser åbnede også op for et større fokus på begrebet slægtskab, der udvikles i nært samspil med køn og gøres uafhængig af essentialiserede biologiseringer, som begrebet i klassisk antropologisk forstand har været hængt op på. De socialkonstruktionistiske analyser anvendte med andre ord teknologien som indgang til analyser af samfundsnormer i forhold til familiedannelse, samtidig med, at det politiske potentiale var at frigøre må- der at gøre familie, køn og slægtskab på. Herved har disse analyser fungeret som et bidrag i en queerteoretisk udvikling. Til gengxld er analyserne klart placeret i en humanistisk/samfundsvidenskabelig selvforståelse, der også reproducerer hvilke dele af kropslighed, teknologi og agens, der kan blive del af analysen.

Den kritik som Haraway og andre feminister med et mere naturvidenskabeligt udgangspunkt påbegyndte i løbet af 80'erne, udfordrede ellers den opdeling af biologisk og socialt køn, der opstod i den anglosaxiske kønsforskning via sex/gender begreberne. Det er det blik og Haraways tanketeknologier som bl.a. cyborgen, som forskere både igennem 90'erne og 00'erne har anvendt i nymaterielle analyser af assisteret befrugtning. De har set et politisk potentiale $\mathrm{i}$ at konceptualisere hvad der foregår på en fertilitetsklinik ved hjælp af figurationer, der skaber rum til at nedbryde dikotomier som natur/kultur, objekt/subjekt og materialitet/diskurs analyser. Det betyder dog ikke at spørgsmålet om ulighed forsvinder. I de nymaterielle analyser, er der også en forholden sig til ulighed og de problemstillinger, der opstår når teknologi, krop og celler agerer i samspil med diskurs. Teknologikritikken ligger $i$ at stille spørgsmålet cui bono?

Selvom ulighed har været med i analyserne fra radikalfeministerne til i dag, kan man sige, at den mere strukturalistiske kritik som radikalfeministerne byggede på, er fundet frem i analyserne af bioøkonomier; analyser der i særdeleshed er udformet pga. den kommercielle udvikling, der har fundet sted i fertilitetsindustrien. Distancen til teknologien genfindes således $\mathrm{i}$ disse analyser med risici for at nye stigmatiseringer af teknologibrugere finder sted. Samtidig kan man sige, at præcis de økonomiske rationaler og deres betydning for hvordan teknologien anvendes, og hvilken betydning køn og krop får, har været underbelyst de senere år.

De forskellige teoretiske tilgange, der er 
etableret ift. analyser af assisteret befrugtning, bør I mine øjne derfor ikke læses som enten eller perspektiver. De kan i stedet læses som partielle positioner, der skaber mulighed for forskellige former for viden og teoretiske begrebsliggørelser, og de rummer forskellige politiske potentialer. Samtidig med at man kan problematisere radikalfeministerne for at udvikle en teknologikritik, der var med til at stigmatisere infertile og konstruere essentialistiske kønsforestillinger, bidrager en analyse af salg af kropsdele til forståelser af den globale undertrykkelse som salg af kropsdele kan skabe mulighed for.

Braidottis anvendelse af figurationen 'det nomadiske subjekt' er i mine øjne en brugbar feministisk figuration til at åbne øjnene op for de forskellige muligheder feministiske analyser af assisteret befrugtning har etableret, både ift. teknologisyn og begrebsforståelser af fx køn og slægtskab. Forhåbentlig kan denne kartografi i samspil med det nomadisk subjekt, og min opfordring til at anvende den feministiske genealogi som kognitivt redskab, inspirere den fremtidige udvikling af feministisk teori. For selvom assisteret befrugtning har en del år på bagen og har skiftet karakter fra at være eksperimentel til at være konventionel, er den teknologiske udvikling og teknologiens kreative anvendelsesmuligheder ikke stoppet. Derfor er spørgsmålet om hvordan vi kan og bør leve med teknologier som assisteret befrugtning, på ingen måder udtømt - og både teknologisyn og begreber som køn og slægtskab vil blive vendt og drejet på ny fremover.

\section{Noter}

1. For at begrænse mig fokuserer jeg i denne artikel på analyser af assisteret befrugtning og ikke alle de mange forskellige reproduktionsteknologier som assisteret befrugtning ofte diskuteres i samspil med.

2. Kartografi henviser til kortlægningspraksis. Jeg er inspireret af Nina Lykkes anvendelse af begrebet (Lykke 2002: 133-143). Kartografi skaber mulighed for at tænke teoretiske positioner uden at skrive udviklingen frem som en entydig teleologisk fremstilling.

3. I USA og England kaldes børn skabt ved hjælp af selvinsemination også "turkey baster babies". 4. I Hornsteins (1984) artikel beskrives, hvordan donorinsemination er blevet udviklet som en selvhjxlpsteknologi til lesbiske og enlige kvinder af kvinder selv. De beskriver, hvordan disse teknologier blev udviklet og udbredt i slutningen af 70'erne og starten af 80 'erne for at skabe muligheder for andre familieformer. I USA blev alternative sædbanker etableret som fx Oakland Feminist Women's Health Center, der blev oprettet i 1982, Hornstein (1984:376).

5. Samtidig med at assisteret befrugtning styret af læger blev betragtet som problematisk, blev selvinsemination anvendt og diskuteret som en måde at fă børn, hvor kvinder selv styrede teknologien (Adrian 2006: 31)

6 . Udover at de hormonelle præparater er blevet udviklet og forbedret så man i stigende grad anvender lavdosis hormonstimulering, har man ændret æxudtagningsprocessen radikalt. Tidligere blev xggene udtaget ved hjælp af laproskopi under fuld narkose. I dag foregår det vaginalt via en nål, der stikkes ind gennem vagina, og kan kontrolleres ved hjælp af ultralydsscanning. Denne praksis blev førstegang anvendt i 1980 af Susan Lenz, en dansk kvindelig gynækolog.

7. Franklin udfører en indgående analyse af jomfrufødseldebatten, og inspireret af Collier og Yanagisako beskriver hun, hvordan køn og slægtskab er blevet opfattet og defineret i samspil.

8. Anvendelsen af termen nymaterialisme handler ikke så meget om nyhedsværdien som en måde at adskille denne form for materialisme, fra den marxistiske teoriretning historisk materialisme. I Barads og Haraways version er det dog væsentligt at understrege at de også lader sig inspirere af kritisk teori.

9. Cyborgbegrebet udviklede Haraway allerede i 1983 som figuration (1991:243)

10. Haraway spiller som teoretiker denne helt centrale rolle, fordi Cyborg-manifestet er en klassiker både i science and technology studies og i feministisk teori. Cyborg Manifestet giver udtryk for en feministisk tilgang til teknologi, der ikke er teknofobisk, men fastholdt en kritik af ulighed.

11. Særligt Barads analyse af ultralydsscanninger har inspireret Adrian (Barad 1998) 


\section{LITTERATURLISTE}

- Adrian, Stine Willum (2010): Sperm stories: Politics and practices of sperm banking in Denmark and Sweden, i: European Journal of Women's Studies $2010 / 4$.

- Adrian, Stine (2006): Nye skabelsesberetninger om ag, sad og embryoner. Et etnografisk studie af skabelser på fertilitetsklinikker og sedbanker. LiU-Tryck, Linköping.

- Almeling, Rene (2007): Selling Genes, Selling Gender: Egg Agencies, Sperm Banks, and the Medical Market in Genetic Material, i: American Sociological Review 2007/3.

- Arditti, Rita; Klein, Renate \& Minden, Shelley (red.) (1984): Test-Tube Women: What Future for Motherhood?. Pandora Press, London.

- Barad, Karen (1998): Getting Real: Technoscientific Practices and the Materialization of Reality, Differences: A Journal of Feminist Cultural Studies 1998/10.

- Becker, Gay (2000): The Elusive Embyo: How Women and Men Approach New Reproductive Technologies. University of California Press, Berkeley.

- Birke, Lynda (1986): Women, Feminism and Biology: The Feminist Challenge. Wheatsheaf, Brighton. - Bryld, Mette (2001): The Infertility Clinic and the Birth of the Lesbian: The Political Debate on Assisted Reproduction in Denmark, i: The European Journal of Women's Studies, 2001/8.

- Butler, Judith (1993): Bodies That Matter. On the discoursive limits of "sex". Routledge, New York - Collier, Jane Fishburne \& Yanagisako, Sylvia Junko (1987): Toward a Unified Analysis of Gender and Kinship, i Collier, Jane Fishburne \& Yanagisako, Sylvia Junko (red.): Gender and Kinship: Essays Toward a Unified Analysis. Stanford University Press, Stanford.

- Corea, Gena (1989a): Surrogacy: Making the Links, i Klein, Renate D. (red.): Infertility Women Speak Out About Their Experiences Of Reproductive Medicine. Pandora Press, London.

. Corea, Gena (1989b): How the New Reproductive Technologies Will Affect All Women, i Hynes, Patricia (red.): Reconstructing Babylon: Essays on Women and Technology. Earthscan Publications, London.

- Corea, Gena (1985a): The Mother Machine: Reproductive Technologies from Artificial Insemination to Artificial Wombs. Harper \& Row, New York.

- Corea, Genoveffa (1984): Egg Snatchers, i Arditti, Rita, Klein, Renate og Minden, Shelly (red.): Test-Tube Women: What Future for Motherhood? Pandora Press, London.

- Corea, Gena, Klein, Renate og Hanmer, Jalna et al. (red.) (1985): Man-Made Women: How New Reproductive Technologies Affect Women. Hutchinson and Co, London.

- Cussins, Charis (1996): Ontological Choreography: Agency Through Objectification in Infertility Clinics, i: Social Studies of Science, 1996/26.

- Dickenson, Donna (2008): Body Shopping. Converting Body Parts to Profit. Oneworld, Oxford.

- Dumit, Joseph og Davis-Floyd, Robbie (1998):

Cyborg Babies, i: Davis-Floyd, Robbie og Dumit, Joseph (red.): Cyborg Babies: From Techno-Sex to Techno-Tots, Routledge, New York.

- Firestone, Shulamith (1970): The Dialectic of Sex: The Case For Feminist Revolution. Bantam Books, New York.

- Franklin, Sarah (2001): Biologization Revisited: Kinship Theory in the Context of the New Biologies, i Franklin, Sarah \& McKinnon, Susan (red.): Relative Values: Reconfiguring Kinship Studies. Duke University Press, Durham.

- Franklin, Sarah (1997): Embodied Progress: $A$ Cultural Account of Assisted Reproduction, Routledge. New York.

- Haraway, Donna (1991): Simians, Cyborgs, and Women: The Reinvention of Nature. Routledge, New York.

- Hornstein, Francie (1984): Children by donor insemination: A new choice for lesbians, I Arditti et al. (Red.) Test-tube women: What future for motherhood?. Pandora Press. London - Inhorn, Marcia \& Gürtin, Zeynep (2011): Crossborder reproductive care: a future research agenda, Reproductive BioMedicine Online. 2011/23.

- Inhorn, Marcia (2003): Local Babies, Global Science: Gender, Religion, and In Vitro Fertalization in Egypt. Routledge, New York.

- Kahn, Susan Martha (2000): Reproducing Jews: A Cultural Account of Assisted Conception in Israel. Duke University Press, Durham.

- Klein, Renate (1989): The Exploitation of Desire: Womens Experience with In Vitro Fertalisation: An Explorative Study. Deakin University Press, Fitzroy. - Koch, Lene (1992): The Fairy Tale as Model for Women's Experience of In Vitro Fertilization, i Bequaert Holmes, Helen (red.): Issues in Reproductive Technology: An Anthology. Garland Publishing, New York/ London.

- Koch, Lene (1989): Ønskebørn: Kvinder og reagensglasbørn. Rosinante, Charlottenlund.

- Kroløkke, Charlotte Halmø \& Pant Saumya (2012): "I only need her uterus": Neo-liberal Discourses on Transnational Surrogacy, i: NORA Nordic Journal of Feminist and Gender Research $2012 / 20$.

· Lenz, Susan \& J Lauritsen (1982): Ultrasonically 
guided percutaneous aspiration of human follicles under local anesthesia: A new method to collect oocytes for in vitro fertilization. Fertil Steril $1982 / 38$.

- Lykke, Nina (2008): Kønsforskning. En guide til feministisk teori, metodologi og skrift. Forlaget Samfundslitteratur, Frederiksberg

- Lykke, Nina (2002): Feminist Cultural Studies of Technoscience and Other Cyborg Studies: A Cartography, i Braidotti, Rosi et al. (red.): The Making of European Women's Studies. Vol. IV, November, ATHENA.

- Madsen, Karen Hvidtfelt (2012): Rugemødre, rejser og nye reproduktionsmetaforer. Weblogs om transnationalt surrogatmoderskab, i: Kultur og Klasse 2012/1.

- Mamo, Laura (2007): Queering Reproduction. Achieving Pregnancy in the Age of Technoscience. Duke University Press, Durham.

- O'Brien, Mary (1981): The Politics of Reproduction. Routledge \& Kegan Paul, Boston.

- Oudshoorn (1994): Beyond the Natural Body: An Archeology of Sex Hormones. Routledge, London.

- Pande, Amrita (2010): Commercial surrogacy in India: Manufacturing a Perfect 'Mother Worker', i: Signs: Journal of Women in Culture and Society 2010/4.

- Petersen, Michael Nebeling (2009): Fra barnets tarv til ligestilling: en queerteoretisk undersøgelse af Folketingets forhandlinger om kunstig befrugtning, i: Kvinder, Køn og Forskning 2009/2.

- Petersson, Birgit (1995): Reproduktionsteknologi - umodenhed og misundelse, i Rosenbeck, Bente \& Schott, Robin May (red.): Forplantning, køn og teknologi. Museum Tusculanums Forlag,

København.

- Pfeffer, Naomi (1987): Artificial Insemination, In-vitro Fertilization and the Stigma of Infertility, i Stanworth, Michelle (red.): Reproductive Technologies: Gender, Motherhood and Medicine. Polity Press, Oxford.

- Pfeffer, Naomi \& Woollett, Anne (1983): The Experience of Infertility. Virago, London.

- Piercy, Marge (1976): Women on the Edge of Time. Fawcett Crest Books, New York.

- Roberts, Elizabeth (2012): God's Laboratory. Assisted Reproduction in the Andes. University of California Press, Berkeley.

- Rothman, Barbara Katz (1986): The Tentative

Pregnancy: Prenatal Diagnosis and the Future of

Motherhood. Viking, New York.

- Rudrappa, Sharmila (2012): India's Reproductive Assembly Line. Contexts 2012/2
- Sandelowski, Margarete (1993): With Child in Mind: Studies of the Personal Encounter with Infertility. University of Pensylvania Press, Philadelphia. - Schmidt, Matthew \& Moore, Lisa Jean (1998): Constructing a "Good Catch," Picking a Winner: The Development of Technosemen and the Deconstruction of the Monolithic Male, i: DavisFloyd, Robbie \& Dumit, Joseph (red.): Cyborg Babies: From Techno-Sex to Techno-Tots. Routledge, New York.

- Spilker, Kristin (2008): Assistert slektskap. Biopolitikk I reproduksjonsteknologiens tidsalder. NTNUtrykk, Trondheim.

- Stanworth, Michelle (red.) (1987): Reproductive Technologies: Gender, Motherhood and Medicine. Polity Press, Oxford.

- Star, Susan Leigh (1991): Power, Technology and the Phenomenology of Conventions:On being allergic to onions. i Johns Law (red.): Sociology of Monsters: Essays on Power, Technology and Domination. Routledge, London

- Stormhøj, Christel (2002): Queering the Family: Critical Reflections on State-regulated Heteronormativity in the Scandinavian Countries, i: Söderström, Göran \& Magnusson, Jan (red.), Farväl heteronormativitet, Lambda Nordica Förlag. - Strathern, Marilyn (1992): Reproducing the Future: Anthropology, Kinship and the New Reproductive Technologies. Manchester University Press, Manchester.

- Thompson, Charis (2005): Making Parents: The Ontological Choreography of Reproductive Technologies. The MIT Press, Cambridge.

- Throsby, Karen (2004): When IVF Fails: Feminism, Infertility and the Negotiation of Normality. Palgrave Macmillan, New York.

- Tjørnhøj-Thomsen, Tine (1999): Tilblivelseshistorier: Barnløshed, slegtskab og forplantningsteknologi i Danmark. ph.d.-række nr.12, Institut for Antropologi, København.

- Van Dyck, José (1995): Manufacturing Babies and Public Consent: Debating the New Reproductive Technologies. Macmillan, London.

- Waldby, Cathrine \& Mitchell, Robert (2006): Tissue Economies: Blood, Organs, and Cell Lines in Late Capitalism. Duke University Press, Durham - Yanagisako, Sylvia \& Delaney, Carol (1995): Naturalizing Power: Essays in Feminist Cultural Analysis. Routledge, London/New York.

\section{SKAL DET STÅ HER????}

Stine Willum Adrian, adjunkt Institut for læring og filosofi Aalborg Universitet, København 